\title{
Epidermal growth factor receptor (EGFR) mutations are exceptionally rare in thyroid transcription factor (TTF-1)- negative adenocarcinomas of the lung
}

\author{
Neeta Somaiah ${ }^{1, *}$, Mary Jo Fidler $^{2, *}{ }^{*}$ Elizabeth Garrett-Mayer ${ }^{3}$, Amy Wahlquist ${ }^{3}$, \\ Keisuke Shirai ${ }^{3}$, Lela Buckingham², Thomas Hensing ${ }^{4}$, Philip Bonomi ${ }^{2}$, and \\ George R. Simon ${ }^{1}$ \\ ${ }^{1}$ MD Anderson Cancer Center, Houston TX 77004 \\ 2 Rush University Medical Center, Chicago, IL 60612 \\ ${ }^{3}$ Hollings Cancer Center, Medical University of South Carolina, Charleston, SC 29425 \\ ${ }^{4}$ North Shore University Health Systems/University of Chicago, Evanston, IL 60201. \\ * These authors contributed equally to this article
}

Correspondence to: George R. Simon, email: GSimon@mdanderson.org

Key words: TTF-1, EGFR, NSCLC, adenocarcinoma

Received: June 4, $2014 \quad$ Accepted: August 3, $2014 \quad$ Published: August 7, 2014

This is an open-access article distributed under the terms of the Creative Commons Attribution License, which permits unrestricted use, distribution, and reproduction in any medium, provided the original author and source are credited.

\section{ABSTRACT:}

Introduction: Approximately $70 \%$ of lung adenocarcinomas express TTF-1. EGFR mutations are present in $\mathbf{1 3 - 1 5 \%}$ of Western adenocarcinoma patients. This paper investigates TTF1 as a negative predictor of mutant EGFR in lung adenocarcinomas.

Results: In the pilot cohort $(\mathrm{N}=301)$ two of 224 specimens positive for EGFR mutations had negative TTF-1 expression (sensitivity $\mathbf{9 9 . 1 \% , 9 5 \% ~ c o n f i d e n c e ~ i n t e r v a l ~}$ (CI) 96.8-99.9\%). Estimated negative predictive values (NPV) for EGFR mutation prevalence rates of $13 \%$ and $15 \%$ are $99.5 \%$ ( $95 \%$ credible interval (CRI) $98.6 \%-$ $99.9 \%$ ) and $99.4 \%$ (CRI - 98.4\%-99.9\%). For EGFR mutation rates of $13 \%$ and $15 \%$, using validation cohort data (211 patients), the estimated NPVs were $97 \%$ (95\% CRI 92\%-99\%) and $96 \%$ (95\% CRI 91\%-99\%).

Methods: Formalin-fixed paraffin-embedded tumors from lung adenocarcinoma patients were analyzed for EGFR mutations by allele-specific PCR in the 'pilot cohort'. TTF-1 status was documented as positive or negative. Negative predictive value (NPV) for a range of true prevalence of EGFR mutation (1\%-50\%) was estimated using Bayesian modeling. The hypothesis was validated in a separate 'validation' cohort using the same modeling.

Conclusion: An overwhelming majority of TTF-1 negative adenocarcinomas will be negative for EGFR mutations. This finding allows for earlier initiation of chemotherapy in newly diagnosed TTF-1 negative adenocarcinomas of the lung with stage IV disease.

\section{INTRODUCTION}

Distinctive genetic aberrations can induce the proliferation of cancer cells and render them vulnerable to therapeutic targeting by specific inhibitors. Inhibitors of the epidermal growth factor receptor (EGFR) are a prototypic example and have produced consistently high response rates in a subgroup of patients with non-small-cell lung cancer (NSCLC) with activating EGFR mutations [1, 2]. Certain patient and tumor characteristics such as adenocarcinoma histology, never-smoking status, female sex and East Asian origin, increase the probability of having EGFR mutations $[3,4]$. The frequency of these mutations in lung adenocarcinomas for patients in the western hemisphere range between $10-18 \%$ compared to approximately $2 \%$ in other NSCLC histological subtypes [5-7].

TTF-1, encoded by the NKx2 gene, is a homeobox transcription factor that is linked to normal lung 
development and function. Genomic profiling studies in lung cancer cell lines and tumors reveal frequent focal DNA amplification at 14q13.3 [8-11]. TTF-1 amplified lung cancers, exhibit increased RNA and protein expression. However, increased TTF-1 protein expression is not necessarily associated with $T T F-1$ amplification at the DNA level and occurs in different subsets of patients with distinct clinico-pathological and molecular features [12]. TTF-1 protein expression is prevalent in lung adenocarcinomas and is significantly associated with female gender, never-smoking status, presence of EGFR mutations and better overall survival [13-16]. TTF-1 amplification, on the other hand, has been detected in both lung adenocarcinomas (18.9\%) and squamous cell carcinomas $(20.1 \%)$ and correlated significantly with the presence of $K R A S$ mutations in the adenocarcinoma subset $[8-10,17]$. TTF-1 protein expression (standard expression defined as greater than $5 \%$ of tumor cells with moderate $(2+)$ or strong $(3+)$ nuclear staining considered positive) is selectively found in adenocarcinomas of the lung and thyroid cancers and its practical diagnostic utility lies in differentiating adenocarcinomas from pulmonary or non-pulmonary origins. Studies have previously reported that tumors positive for EGFR mutations have a high frequency of TTF-1 positivity though the negative predictive value (NPV) for varying EGFR mutation prevalences have not been previously reported $[18,19]$. We thus proceeded to prove the hypothesis that TTF-1 negative tumors will be wild type for EGFR mutations. The clinical utility of this finding is evident and would justify the earlier initiation of front line cytotoxic chemotherapy in TTF-1 negative advanced stage patients with adenocarcinomas of the lung.

\section{RESULTS}

\section{The pilot cohort}

Of the 301 lung adenocarcinomas samples 224 were positive for EGFR mutations (74\%). Of the 224 mutant
EGFR tumors, 119 had an exon 19 deletion, 84 had an exon 21 mutations (79 patients had L858R and 5 patients had L861Q), 14 had an exon 18 mutation (G719X) and 3 had a resistance mutation $\mathrm{S} 768 \mathrm{I}$ in addition to a sensitizing mutation. Four were labeled as 'deletions' without further classification.

Only 2 (one exon 19 deletion and one L858R mutation) of the 224 specimens positive for EGFR mutations and 28 of the 77 EGFR wild-type patients were TTF-1 negative (Table 1). Thus the sensitivity is $99.1 \%$ (95\% CI: 96.8-99.9\%) and specificity is 36.4\% (95\% CI: 25.7-48.1\%). For assumed EGFR mutation prevalence rates of $13 \%$ and $15 \%$, the estimated NPVs are $99.5 \%$ (95\% CRI: 98.6\%-99.9\%) and 99.4\% (95\% CRI: 98.4\%$99.9 \%$ ), respectively. Even for a prevalence of EGFR mutations as high as $30 \%$ the NPV is 98.5 .

The estimated NPV with the $95 \%$ CRI for a range of EGFR mutation prevalence is shown in Figure 1A. From this model, the estimates of sensitivity and specificity were 98.8\% (95\% CRI 96.8\% - 99.7\%) and 36.4\% (95\% CRI: $26.3 \%-47.4 \%$ ), which are almost identical to the actual observed values noted above. Our analyses using different Beta priors provided very similar inference for true EGFR mutation rates of $13 \%$ and $15 \%: 99.7 \%$ and $99.6 \%$ for a Beta $(0.005,0.005)$ prior and $99.4 \%$ and $99.2 \%$ for a Beta $(2,2)$ prior.

\section{The validation cohort}

In the validation cohort, 131 advanced lung adenocarcinoma patients with known EGFR mutation status and TTF-1 status were analyzed. Twenty-one patients with EGFR mutant tumors were identified, with 12 harboring an exon 19 deletion and 9 harboring a mutation in exon 21.

Only 1 of the 21 EGFR mutation positive specimens and 35 of the 110 EGFR wild-type specimens were TTF1 negative (Table 2), yielding a sensitivity of 95\% (95\% CI: $76 \%-99.9 \%$ ) and specificity of $32 \%$ (95\% CI: $23 \%-$ $41 \%$ ). For true EGFR mutation rates of $13 \%$ and $15 \%$ the estimated NPVs are 97\% (95\% CRI: 90\%-99\%) and

Table 1: Distribution of samples by EGFR mutation and TTF-1 status in the pilot cohort.

\begin{tabular}{l|l|l|l|l|}
\hline & EGFR & Status & \\
\hline & & Mutant & Wild Type & Total \\
\hline \multirow{2}{*}{ TTF-1 } & Positive & 222 & 49 & 271 \\
\cline { 2 - 5 } & Negative & 2 & 28 & 30 \\
\hline & Total & 224 & 77 & 301 \\
\hline
\end{tabular}
Sensitivity $=99.1 \%(95 \%$ CI: $96.8-99.9 \%)$
NPV for EGFR mutation rates of $13 \%=99.5 \%(95 \%$ CRI: $98.6 \%-99.9 \%)$
$($ NPV = Negative Predictive Value $)$


96\% (95\% CRI: 88\%-99\%), respectively (Figure 1B), thus validating our findings in the pilot cohort.

\section{DISCUSSION}

A favorable prognosis for TTF-1 (encoded by NKX2-1) in NSCLC has been documented in many retrospective studies [12-15]. Evaluation of metastatic lesions in mouse models show that TTF-1 is consistently depressed in metastatic versus non-metastatic lung adenocarcinoma [11]. This is potentially mediated by preservation of the epithelial phenotype as TTF1 transactivates e-cadherin and other tight junction molecules via promoter interaction [20-22]. In NKX21 negative mice models with $K R A S$ mutations, reduced tumor volume was seen when TTF-1 expression was induced $[11,23]$. The ability of the TTF-1 protein to confer a favorable prognosis, observed in cell line and xenograft studies, have been corroborated in clinical trials testing front line cytotoxic chemotherapy in patients with stage IV NSCLC [24].

The high negative predictive value exceeding $96 \%$ of TTF-1 for the presence of the activating EGFR gene mutation is intriguing. Cell line data from Yamaguchi et al show receptor tyrosine kinase-like orphan receptor 1 (ROR1) is highly upregulated after introduction of NKX21. ROR1 negatively regulates phosphoinositide 3-kinase (PI3K) and conversely ROR1 knockdowns enhance PI3K activity. ROR1 kinases activity was thought to be required to fully sustain downstream signaling of EGF stimulated EGFR. ROR1 signaling also decreased phosphorylation of phosphatase and tensin homolog (PTEN), and encouraged EGFR-ERBB3 interaction [25]. Though mutations in $E G F R$ are thought to be a driver in adenocarcinomas, it is possible that $T T F-1$ (being a transcription factor) facilitates the transcription of necessary genes to maintain survival signaling and evade apoptosis.

Interestingly, preliminary evidence suggests that there exists an association between the echinoderm microtubule-associated protein-like 4-anaplastic lymphoma kinase (EML4-ALK) translocations, another oncogenic driver, and TTF-1 status. TTF-1 positivity in ALK translocated tumors seems to be present approximately $70 \%$ of the time. The co-expression of p63 is also often seen in these tumors [26-28]. Currently, approximately $60 \%$ of lung adenocarcinomas have now been shown to have mutations (KIF5B-Ret, ROS1, NTRK1, HER2-Neu, to name a few) that may induce and drive these malignancies and the association of TTF-1 status and presence of these driver mutations remains to be elucidated [29-37].

Whether TTF-1 itself has a tumor suppressor or tumor-promoting function awaits further clarification. Multivariate analyses reveal that $T T F-1$ amplification and copy number gain are independent predictors of poor survival in patients with NSCLC [12-14]. Indeed small interfering RNA (siRNA)-mediated knockdown of TTF-1 in lung cancer cell lines with amplification led to reduced cell proliferation, manifested by both decreased cell-cycle progression and increased apoptosis indicating that TTF-1 amplification is a lineage-specific oncogene in lung cancer [8-11]. Thus protein expression and DNA amplification of $T T F-1$ have divergent implications in patients with lung cancer and a clearer understanding of this phenomenon would further clarify the significance of the association between certain driver mutations and the expression of the TTF-1 protein [32].

In this study the sensitivity and specificity for TTF1 and the presence of EGFR gene mutation was lower in the validation cohort than the pilot cohort. These differences may be accounted for by differences in EGFR gene mutation testing methods. The most common mutations associated with sensitivity to EGFR tyrosine kinase inhibitors are exon 19 deletions and by point mutations in exon 21 (L858R). These two mutations account for approximately $90 \%$ of all EGFR mutations [38]. In our pilot cohort, specimens were analyzed for all known EGFR mutations, and these two common account for $90 \%$ of the mutation. In our validation cohort, specimens were analyzed only for two common mutations, and conceivably, if the rare mutations were also included, the sensitivity and the NPV might have been higher.

Current guidelines recommend testing all nonsquamous NSCLCs for EGFR mutations, and treating mutation positive patients with EGFR tyrosine kinase

Table 2: Distribution of samples by EGFR mutation and TTF-1 status in the validation cohort.

\begin{tabular}{|l|l|l|l|l|}
\hline & & EGFR & Status & \\
\hline & & Mutant & Wild Type & Total \\
\hline \multirow{2}{*}{ TTF-1 } & Positive & 20 & 75 & 95 \\
\cline { 2 - 5 } & Negative & 1 & 35 & 36 \\
\hline & Total & 21 & 110 & 131 \\
\hline
\end{tabular}

Sensitivity $=95 \%$ (95\% CI: 76\%-99.9\%)

NPV for EGFR mutation rates of 13\%=97\% (95\% CRI: 90\%-99\%)

NPV for EGFR mutation rates of $15 \%=96 \%$ (95\% CRI: 88\%-99\%).

$(\mathrm{NPV}=$ Negative Predictive Value) 
inhibitors (TKIs) first-line. Several randomized trials have validated this approach [39-43]. However, most institutions and community cancer centers depend on centralized CLIA-certified laboratories for testing. This entails sending tissue for analysis and waiting several weeks before EGFR mutation results become available, whereas TTF-1 status is conveniently available with the institutional pathology report. Our data demonstrates that patients with adenocarcinomas of the lung who are TTF1 negative have at least a $96 \%$ chance of being EGFR wild type when the prevalence of EGFR mutations is approximately $15 \%$. This allows for early initiation of front-line chemotherapy in patients with bronchogenic adenocarcinoma which is TTF-1 negative.

\section{METHODS}

To test the above outlined hypothesis, data were acquired from tissue samples sent by treating medical oncologists to a central reference Clinical Laboratory Improvement Amendments (CLIA) certified laboratory (Response Genetics Inc., Los Angeles, CA) for EGFR mutation testing (Pilot cohort). Samples were reviewed for EGFR mutation status and TTF-1 status. Microdissected formalin-fixed paraffin-embedded tumors were used for $E G F R$ mutation analysis by allele-specific polymerase chain reaction (PCR) to identify all known EGFR mutations (exon 18-21). TTF-1 status was based on IHC staining of the tumor specimen as recorded on the accompanying pathology report (required to be done in a CLIA certified clinical pathology laboratory). As the pilot data set is composed of specimens sent by physician referral, the pilot set was highly enriched for the presence of EGFR mutations. Adenocarcinoma specimens with known TTF-1 status were analyzed for any of the above identified EGFR mutations and coded as mutant vs. wildtype.

For the Validation cohort, stage IV lung adenocarcinoma patients treated with erlotinib at Rush University Medical Center, Chicago, IL and Evanston Hospital, Evanston, IL were included if there was sufficient tissue available for EGFR mutation testing and TTF-1 status was known. Patients' tumors were analyzed for only the two most common mutations that are associated with sensitivity to EGFR tyrosine kinase inhibitors (exon 19 deletion or exon 21 L858R point mutation) using single-strand conformation polymorphism (SSCP) and sequence-specific PCR. Tumors were labeled wild-type if these two common mutations were absent.

\section{Statistical considerations}

Descriptive statistics were used to summarize characteristics of patients whose samples were included in the analysis. Sensitivity and specificity were calculated, representing the probability of a TTF-1 positive result given that an EGFR mutation is present, and the probability of a TTF-1 negative result given no evidence of the presence of an EGFR mutation, respectively. Exact 95\% confidence intervals were calculated. Because the prevalence of the EGFR mutations in the pilot data group of lung adenocarcinomas was not reflective of the true prevalence in most clinical settings, the negative predictive value (NPV) generated from our pilot data would not provide an accurate estimate of the NPV of TTF-1 in a clinical setting in the US, where it has been shown that approximately $10-18 \%$ of patients with advanced stage lung adenocarcinomas have an EGFR mutation $[5,7]$. However, NPV can be calculated as function of sensitivity (Sens) and specificity (Spec) for another assumed EGFR mutation prevalence $(\pi)$ using Bayes rule:

$$
N P V=\frac{\operatorname{Spec}(1-\pi)}{\operatorname{Spec}(1-\pi)+(1-\operatorname{Sens}) \pi}
$$

We considered values of prevalence of EGFR from $p=0.01$ to 0.50 . Although estimation of NPV using the above relationship between NPV, sensitivity, specificity and prevalence is simple, the estimation of the precision of NPV requires statistical modeling. A Bayesian estimation approach was used where TTF-1 results were assumed to follow binomial distributions, based on EGFR status and $\operatorname{Beta}(1,1)$ priors were used for modeling sensitivity and specificity. Beta $(1,1)$ is considered a "weak" or "flat" prior. WinBugs14, a Gibbs sampler software program, was used for model fitting. Separate models were fit to estimate NPV over a range of assumed true EGFR mutation prevalences ( $1 \%$ to $50 \%$ prevalence). From these posterior distributions, for each of the assumed prevalences, the median, $2.5^{\text {th }}$ and $97.5^{\text {th }}$ quintiles provide point estimates and $95 \%$ credible intervals for the NPV. CI refers to confidence intervals and CRI refers to credible intervals.

The Gibbs sampler was run multiple times with different starting values to ensure convergence of results. Trace plots were also examined. A burn-in of 50,000 iterations was used. Fifty thousand iterations were rerun where every $10^{\text {th }}$ iteration was saved for generating posterior distributions. The Gibbs sampler was also rerun using a Beta $(0.005,0.005)$ prior (which favors very high and low probability values but is relatively flat for most values between 0.02 and 0.98 ) and a $\operatorname{Beta}(2,2)$ prior (which favors probability values near 0.50 relative to high and low values) to ensure the results were not sensitive to the choice of prior.

\section{CONCLUSION}

Our findings that EGFR mutations are associated with TTF-1 expression have significant clinical and biological implications. Chemotherapy can be initiated in stage IV patients with TTF-1 negative adenocarcinoma 
of the lung, while their mutation testing is awaited. In capital constrained clinical practice settings, our findings will enable the more optimal utilization of both financial and personnel resources. Additionally study of TTF-1 related molecular pathways might provide new insights regarding cancer initiation, progression, and treatment for this relatively large group of non-small cell lung cancer patients.

\section{ACKNOWLEDGMENTS}

This study was performed at the Cancer Center, Medical University of South Carolina, Charleston, SC; MD Anderson Cancer Center, Houston, TX; Rush University Medical Center, Chicago, IL and North Shore University Health Systems/University of Chicago, Evanston, IL. The molecular analysis for the Pilot cohort was performed at the Response Genetics Laboratory, Los Angeles, CA.

\section{REFERENCES}

1. Lynch TJ, Adjei AA, Bunn PA, Jr., DuBois RN, Gandara DR, Giaccone G, Govindan R, Herbst RS, Johnson BE, Khuri FR, Perez-Soler R, Rosell R, Rowinsky EK, Sandler $\mathrm{AB}$, Scagliotti GV, Schiller JH, et al. Novel agents in the treatment of lung cancer: conference summary statement. Clin Cancer Res. 2004; 10: 4199s-4204s.

2. Tsao MS, Sakurada A, Cutz JC, Zhu CQ, Kamel-Reid S, Squire J, Lorimer I, Zhang T, Liu N, Daneshmand M, Marrano P, da Cunha Santos G, Lagarde A, Richardson F, Seymour L, Whitehead M, et al. Erlotinib in lung cancer - molecular and clinical predictors of outcome. N Engl J Med. 2005; 353: 133-144.

3. Pao W, Miller V, Zakowski M, Doherty J, Politi K, Sarkaria I, Singh B, Heelan R, Rusch V, Fulton L, Mardis E, Kupfer D, Wilson R, Kris M and Varmus H. EGF receptor gene mutations are common in lung cancers from "never smokers" and are associated with sensitivity of tumors to gefitinib and erlotinib. Proc Natl Acad Sci U S A. 2004; 101: 13306-13311.

4. Pham D, Kris MG, Riely GJ, Sarkaria IS, McDonough T, Chuai S, Venkatraman ES, Miller VA, Ladanyi M, Pao W, Wilson RK, Singh B and Rusch VW. Use of cigarettesmoking history to estimate the likelihood of mutations in epidermal growth factor receptor gene exons 19 and 21 in lung adenocarcinomas. J Clin Oncol. 2006; 24: 1700-1704.

5. Marchetti A, Martella C, Felicioni L, Barassi F, Salvatore S, Chella A, Camplese PP, Iarussi T, Mucilli F, Mezzetti A, Cuccurullo F, Sacco R and Buttitta F. EGFR mutations in non-small-cell lung cancer: analysis of a large series of cases and development of a rapid and sensitive method for diagnostic screening with potential implications on phar macologic treatment. J Clin Oncol. 2005; 23: 857-865.
6. Paez JG, Janne PA, Lee JC, Tracy S, Greulich H, Gabriel S, Herman P, Kaye FJ, Lindeman N, Boggon TJ, Naoki K, Sasaki H, Fujii Y, Eck MJ, Sellers WR, Johnson BE, et al. EGFR mutations in lung cancer: correlation with clinical response to gefitinib therapy. Science. 2004; 304: 1497-1500.

7. Bell DW, Lynch TJ, Haserlat SM, Harris PL, Okimoto RA, Brannigan BW, Sgroi DC, Muir B, Riemenschneider MJ, Iacona RB, Krebs AD, Johnson DH, Giaccone G, Herbst RS, Manegold C, Fukuoka M, et al. Epidermal growth factor receptor mutations and gene amplification in nonsmall-cell lung cancer: molecular analysis of the IDEAL/ INTACT gefitinib trials. J Clin Oncol. 2005; 23: 8081-8092.

8. Weir BA, Woo MS, Getz G, Perner S, Ding L, Beroukhim R, Lin WM, Province MA, Kraja A, Johnson LA, Shah K, Sato M, Thomas RK, Barletta JA, Borecki IB, Broderick $\mathrm{S}$, et al. Characterizing the cancer genome in lung adenocarcinoma. Nature. 2007; 450: 893-898.

9. Tanaka H, Yanagisawa K, Shinjo K, Taguchi A, Maeno K, Tomida S, Shimada Y, Osada H, Kosaka T, Matsubara H, Mitsudomi T, Sekido Y, Tanimoto M, Yatabe Y and Takahashi T. Lineage-specific dependency of lung adenocarcinomas on the lung development regulator TTF1. Cancer Res. 2007; 67: 6007-6011.

10. Kwei KA, Kim YH, Girard L, Kao J, Pacyna-Gengelbach M, Salari K, Lee J, Choi YL, Sato M, Wang P, HernandezBoussard T, Gazdar AF, Petersen I, Minna JD and Pollack JR. Genomic profiling identifies TITF1 as a lineage-specific oncogene amplified in lung cancer. Oncogene. 2008; 27 : 3635-3640.

11. Winslow MM, Dayton TL, Verhaak RG, Kim-Kiselak C, Snyder EL, Feldser DM, Hubbard DD, DuPage MJ, Whittaker CA, Hoersch S, Yoon S, Crowley D, Bronson RT, Chiang DY, Meyerson M and Jacks T. Suppression of lung adenocarcinoma progression by Nkx2-1. Nature. 2011; 473: 101-104.

12. Barletta JA, Perner S, Iafrate AJ, Yeap BY, Weir BA, Johnson LA, Johnson BE, Meyerson M, Rubin MA, Travis WD, Loda $M$ and Chirieac LR. Clinical significance of TTF-1 protein expression and TTF-1 gene amplification in lung adenocarcinoma. Journal of cellular and molecular medicine. 2009; 13: 1977-1986.

13. Anagnostou VK, Syrigos KN, Bepler G, Homer RJ and Rimm DL. Thyroid transcription factor 1 is an independent prognostic factor for patients with stage I lung adenocarcinoma. J Clin Oncol. 2009; 27: 271-278.

14. Berghmans T, Paesmans M, Mascaux C, Martin B, Meert AP, Haller A, Lafitte JJ and Sculier JP. Thyroid transcription factor 1-a new prognostic factor in lung cancer: a metaanalysis. Ann Oncol. 2006; 17: 1673-1676.

15. Tang X, Kadara H, Behrens C, Liu DD, Xiao Y, Rice D, Gazdar AF, Fujimoto J, Moran C, Varella-Garcia M, Lee JJ, Hong WK and Wistuba, II. Abnormalities of the TITF-1 lineage-specific oncogene in NSCLC: implications in lung cancer pathogenesis and prognosis. Clin Cancer Res. 2011; 17: 2434-2443. 
16. Kendal W, Eapen L and Nicholas G. Second primary cancers after prostatic irradiation: ensuring an appropriate analysis. Cancer. 2007; 109: 164; author reply 165.

17. Kendall J, Liu Q, Bakleh A, Krasnitz A, Nguyen KC, Lakshmi B, Gerald WL, Powers S and Mu D. Oncogenic cooperation and coamplification of developmental transcription factor genes in lung cancer. Proc Natl Acad Sci U S A. 2007; 104: 16663-16668.

18. Sun PL, Seol H, Lee HJ, Yoo SB, Kim H, Xu X, Jheon S, Lee CT, Lee JS and Chung JH. High incidence of EGFR mutations in Korean men smokers with no intratumoral heterogeneity of lung adenocarcinomas: correlation with histologic subtypes, EGFR/TTF-1 expressions, and clinical features. J Thorac Oncol. 2012; 7: 323-330.

19. Gahr S, Stoehr R, Geissinger E, Ficker JH, Brueckl WM, Gschwendtner A, Gattenloehner S, Fuchs FS, Schulz C, Rieker RJ, Hartmann A, Ruemmele P and Dietmaier W. EGFR mutational status in a large series of Caucasian European NSCLC patients: data from daily practice. Br J Cancer. 2013; 109: 1821-1828.

20. Runkle EA, Rice SJ, Qi J, Masser D, Antonetti DA, Winslow MM and Mu D. Occludin is a direct target of thyroid transcription factor-1 (TTF-1/NKX2-1). J Biol Chem. 2012; 287: 28790-28801.

21. Saito RA, Watabe T, Horiguchi K, Kohyama T, Saitoh $\mathrm{M}$, Nagase $\mathrm{T}$ and Miyazono $\mathrm{K}$. Thyroid transcription factor-1 inhibits transforming growth factor-betamediated epithelial-to-mesenchymal transition in lung adenocarcinoma cells. Cancer Res. 2009; 69: 2783-2791.

22. Maeda Y, Tsuchiya T, Hao H, Tompkins DH, Xu Y, Mucenski ML, Du L, Keiser AR, Fukazawa T, Naomoto Y, Nagayasu T and Whitsett JA. Kras(G12D) and Nkx2-1 haploinsufficiency induce mucinous adenocarcinoma of the lung. J Clin Invest. 2012; 122: 4388-4400.

23. Snyder EL, Watanabe H, Magendantz M, Hoersch S, Chen TA, Wang DG, Crowley D, Whittaker CA, Meyerson M, Kimura $\mathrm{S}$ and Jacks T. Nkx2-1 represses a latent gastric differentiation program in lung adenocarcinoma. Mol Cell. 2013; 50: 185-199.

24. Gronberg BH, Lund-Iversen M, Strom EH, Brustugun OT and Scott H. Associations between TS, TTF-1, FR-alpha, FPGS, and overall survival in patients with advanced non-small-cell lung cancer receiving pemetrexed plus carboplatin or gemcitabine plus carboplatin as first-line chemotherapy. J Thorac Oncol. 2013; 8: 1255-1264.

25. Yamaguchi T, Yanagisawa K, Sugiyama R, Hosono Y, Shimada Y, Arima C, Kato S, Tomida S, Suzuki M, Osada $\mathrm{H}$ and Takahashi T. NKX2-1/TITF1/TTF-1-Induced ROR1 is required to sustain EGFR survival signaling in lung adenocarcinoma. Cancer Cell. 2012; 21: 348-361.

26. Yoshida A, Tsuta K, Watanabe S, Sekine I, Fukayama M, Tsuda H, Furuta K and Shibata T. Frequent ALK rearrangement and TTF-1/p63 co-expression in lung adenocarcinoma with signet-ring cell component. Lung Cancer. 2011; 72: 309-315.
27. Kim S, Kim TM, Kim DW, Go H, Keam B, Lee SH, Ku JL, Chung DH and Heo DS. Heterogeneity of Genetic Changes Associated with Acquired Crizotinib Resistance in ALKRearranged Lung Cancer. J Thorac Oncol. 2013; 8: 415422 .

28. Inamura K, Takeuchi K, Togashi Y, Hatano S, Ninomiya H, Motoi N, Mun MY, Sakao Y, Okumura S, Nakagawa K, Soda M, Choi YL, Mano H and Ishikawa Y. EML4-ALK lung cancers are characterized by rare other mutations, a TTF-1 cell lineage, an acinar histology, and young onset. Mod Pathol. 2009; 22: 508-515.

29. Krishnaswamy S, Kanteti R, Duke-Cohan JS, Loganathan S, Liu W, Ma PC, Sattler M, Singleton PA, Ramnath N, Innocenti F, Nicolae DL, Ouyang Z, Liang J, Minna J, Kozloff MF, Ferguson MK, et al. Ethnic differences and functional analysis of MET mutations in lung cancer. Clin Cancer Res. 2009; 15: 5714-5723.

30. Kwak EL, Bang YJ, Camidge DR, Shaw AT, Solomon B, Maki RG, Ou SH, Dezube BJ, Janne PA, Costa DB, Varella-Garcia M, Kim WH, Lynch TJ, Fidias P, Stubbs H, Engelman JA, et al. Anaplastic lymphoma kinase inhibition in non-small-cell lung cancer. N Engl J Med. 2010; 363: 1693-1703.

31. Ohashi K, Sequist LV, Arcila ME, Lovly CM, Chen X, Rudin CM, Moran T, Camidge DR, Vnencak-Jones CL, Berry L, Pan Y, Sasaki H, Engelman JA, Garon EB, Dubinett SM, Franklin WA, et al. Characteristics of lung cancers harboring NRAS mutations. Clin Cancer Res. 2013; 19: 2584-2591.

32. Suehara Y, Arcila M, Wang L, Hasanovic A, Ang D, Ito T, Kimura Y, Drilon A, Guha U, Rusch V, Kris MG, Zakowski MF, Rizvi N, Khanin R and Ladanyi M. Identification of KIF5B-RET and GOPC-ROS1 fusions in lung adenocarcinomas through a comprehensive mRNA-based screen for tyrosine kinase fusions. Clin Cancer Res. 2012; 18: 6599-6608.

33. Arcila ME, Chaft JE, Nafa K, Roy-Chowdhuri S, Lau C, Zaidinski M, Paik PK, Zakowski MF, Kris MG and Ladanyi M. Prevalence, clinicopathologic associations, and molecular spectrum of ERBB2 (HER2) tyrosine kinase mutations in lung adenocarcinomas. Clin Cancer Res. 2012; 18: 4910-4918.

34. Mazieres J, Peters S, Lepage B, Cortot AB, Barlesi F, BeauFaller M, Besse B, Blons H, Mansuet-Lupo A, Urban T, Moro-Sibilot D, Dansin E, Chouaid C, Wislez M, Diebold J, Felip E, et al. Lung cancer that harbors an HER2 mutation: epidemiologic characteristics and therapeutic perspectives. J Clin Oncol. 2013; 31: 1997-2003.

35. Gautschi O, Pauli C, Strobel K, Hirschmann A, Printzen G, Aebi S and Diebold J. A patient with BRAF V600E lung adenocarcinoma responding to vemurafenib. J Thorac Oncol. 2012; 7: e23-24.

36. Bergethon K, Shaw AT, Ou SH, Katayama R, Lovly CM, McDonald NT, Massion PP, Siwak-Tapp C, Gonzalez A, Fang R, Mark EJ, Batten JM, Chen H, Wilner KD, Kwak 
EL, Clark JW, et al. ROS1 rearrangements define a unique molecular class of lung cancers. J Clin Oncol. 2012; 30: 863-870.

37. Takeuchi T, Tomida S, Yatabe Y, Kosaka T, Osada H, Yanagisawa K, Mitsudomi T and Takahashi T. Expression profile-defined classification of lung adenocarcinoma shows close relationship with underlying major genetic changes and clinicopathologic behaviors. J Clin Oncol. 2006; 24: 1679-1688.

38. Lynch TJ, Bell DW, Sordella R, Gurubhagavatula S, Okimoto RA, Brannigan BW, Harris PL, Haserlat SM, Supko JG, Haluska FG, Louis DN, Christiani DC, Settleman J and Haber DA. Activating mutations in the epidermal growth factor receptor underlying responsiveness of non-small-cell lung cancer to gefitinib. N Engl J Med. 2004; 350: 2129-2139.

39. Socinski MA, Evans T, Gettinger S, Hensing TA, Sequist LV, Ireland B and Stinchcombe TE. Treatment of stage IV non-small cell lung cancer: Diagnosis and management of lung cancer, 3rd ed: American College of Chest Physicians evidence-based clinical practice guidelines. Chest. 2013; 143(5 Suppl): e341S-368S.

40. Ettinger DS, Akerley W, Borghaei H, Chang AC, Cheney
RT, Chirieac LR, D’Amico TA, Demmy TL, Govindan R, Grannis FW, Jr., Grant SC, Horn L, Jahan TM, Komaki R, Kong FM, Kris MG, et al. Non-small cell lung cancer, version 2.2013. J Natl Compr Canc Netw. 2013; 11: 645653; quiz 653.

41. Mok TS, Wu YL, Thongprasert S, Yang CH, Chu DT, Saijo N, Sunpaweravong P, Han B, Margono B, Ichinose Y, Nishiwaki Y, Ohe Y, Yang JJ, Chewaskulyong B, Jiang H, Duffield EL, et al. Gefitinib or carboplatin-paclitaxel in pulmonary adenocarcinoma. N Engl J Med. 2009; 361: $947-$ 957.

42. Maemondo M, Inoue A, Kobayashi K, Sugawara S, Oizumi $\mathrm{S}$, Isobe $\mathrm{H}$, Gemma A, Harada M, Yoshizawa H, Kinoshita I, Fujita Y, Okinaga S, Hirano H, Yoshimori K, Harada T, Ogura T, et al. Gefitinib or chemotherapy for non-small-cell lung cancer with mutated EGFR. N Engl J Med. 2010; 362: 2380-2388.

43. Sequist LV, Yang JC, Yamamoto N, O’Byrne K, Hirsh V, Mok T, Geater SL, Orlov S, Tsai CM, Boyer M, Su WC, Bennouna J, Kato T, Gorbunova V, Lee KH, Shah R, et al. Phase III Study of Afatinib or Cisplatin Plus Pemetrexed in Patients With Metastatic Lung Adenocarcinoma With EGFR Mutations. J Clin Oncol. 2013; 31: 3327-3334. 